\title{
REGIONAL DISTRIBUTION OF TECHNOLOGY-INTENSIVE MANUFACTURING INDUSTRIES IN THE CZECH REPUBLIC WITH AN ACCENT ON RISK OF DELOCALISATION
}

\author{
Jan Ženka, Vladislav Čadil*
}

\begin{abstract}
The goal of this article is to determine whether low capital intensive firms, characterised by low productivity and low level of R\&D activities that operate in technologically intensive branches of the Czech manufacturing industry, tend to be localised in economically lagging regions which are attractive for costs seeking FDI. We wanted to determine to the Czech regions that are more threatened by delocalisation of manufacturing activities. The assessment of companies' localisation stability is based on 3 economic indicators representing internal keep-factors of delocalisation - capital intensity, complexity of value chain, and sophistication of production processes. We did not confirm the hypothesis on concentration of footloose firms in economically lagging districts with high unemployment and accessibility of investment incentives. These firms, which are considered to be the most predisposed for delocalisation, are geographically dispersed. Localisation of technologically intensive branches corresponds neither to the settlement hierarchy nor to the economic performance of districts. Regional differences of indicators of localisation stability exhibit a strong path dependency effect.
\end{abstract}

Keywords: delocalisation, manufacturing, regional disparities, Czech Republic

JEL Classification: L16, L23, L25, O18

\section{Introduction}

Technology and knowledge-intensive activities play the most important role in the economic development of economically developed states as well as countries in transition (Dicken, 2003). The shift towards technology-intensive industries is often connected with the beginning of the $5^{\text {th }}$ Kondratieff's wave (Agnew, Knox, 1998; Berry, Conkling, Ray, 1997; Hall, 1988), dawn of the post-industrial society (Bell, 1973), creation of knowledge economy (Rooney, Hearn, Ninan, 2005), offensive restructuring implying forward strategic orientation, new products development based on progressive technologies, and R\&D investment (Carlin et al., 1997; Erickson, 1987; Szalavetz, 2007; Lipietz, 1992).

Technology-intensive industries (high-tech and medium-high-tech) characterised by high level of innovation, high value added, high wages and profits are competitive

* Jan Ženka, Czech Statistical Office, Na padesátém 81, CZ - 10082 Praha 10

(janzenka@gmail.com); Vladislav Čadil, Technology Centre AS CR, Rozvojová 135, CZ - 16502 (cadil@tc.cz). 
thanks to high quality standards and high prices. In the Czech Republic, the importance of medium-high-tech as well as high-tech branches has been increasing under the influence of industrial restructuring driven by foreign direct investment (Čadil, 2007). In 2005, the share of medium-high-tech branches reached $35.1 \%$ in production, $35 \%$ in gross value added and $30.3 \%$ in employment. The share of high-tech branches was significantly lower with $10.6 \%$ in production, $6.4 \%$ in gross value added and $6.9 \%$ in employment (Kadeřábková, 2007b).

The sector of medium-high-tech and high-tech firms is very heterogeneous in productivity and real technological intensity (the share of $R \& D$ on value added) (Kadeřábková, 2007a, b). The Czech high-tech branches exhibit low values of both indicators, which had been declining in 2001-2005 (Rojiček, 2006). The main cause of this decline lies in the years 2001 and 2002 when new production facilities were being built. These facilities are now focused on assembly activities and product finalisation from imported components (inward processing procedure), and generate minimal share of value added in production (Lexa, Rojíček, 2007). Computer manufacturing oriented on completion and reexport of imported components is the extreme case of low productivity and low value added in high-tech manufacturing industries (Kadeřábková, 2005).

In the Czech Republic, the medium-high-tech industries tend to exhibit the highest level and best growth dynamics of labour productivity (Rojíček, 2007). The automotive industry unambiguously plays the role of the main leader and innovator, stimulating development of many established industries and the Czech economy as a whole (Pavlínek, 2003). However, even among the leaders there are firms with low R\&D expenditures, productivity and innovation activities (Ženka, 2008). These firms are in many cases MNEs' subsidiaries whose entry into the Czech economy was motivated by reduction of production costs and utilisation of investment incentives.

This type of economic activities is not long-term sustainable, because costs of production factors have been rapidly growing. Investors, who base the competitiveness of their subsidiaries on temporary competitive advantages in low-costs countries, are the most likely to delocalise their economic activities (Pennings, Sleuwaegen, Monmaerts, 2000; Tiggeloove, Vossen, 2005). Against expectations, the majority of jobs jeopardised by delocalisation is not allocated in labour intensive branches like manufacturing of clothes and leather products, but in technology-intensive branches manufacturing of electric equipment, car components and computers (Ženka, 2008).

Cost oriented investments that flow into building of assembly halls are considered "footloose" - not having specific localisation claims to labour force qualification, proximity of suppliers, clients, universities and other R\&D institutions. We expect that footloose investments will be more likely localised in regions offering opportunity for the highest costs reduction. In the Czech Republic, these regions would be peripheral, structurally affected, and with high unemployment rate, offering relatively low prices of realities and labour force, as well as available and very favourable investment incentives.

Our aim is to determine whether assembly activities (characterised by low productivity and real technological intensity) of technology-intensive branches are rather localised in economically less developed regions with high unemployment rate and available investment incentives. This would allow us to pinpoint the type of regions 
that are most threatened by delocalisation of manufacturing activities. We do not consider only greenfield investment and foreign owned companies, our analysis also includes Czech-owned firms that often play a marginal role as suppliers of unsophisticated components (Pavlínek, Janák, 2007). These firms are considered since the peripheral position and unfavourable economic structure of regions can be both a reason and a result of localisation of firms exhibiting low production, technological and capital intensity.

\section{Theoretical Framework}

Delocalisation means transfer of productive as well as non-productive activities abroad. Veugelers (2005, pp. 4-5) uses a broader definition: "delocalisation is the process of shifting economic activities towards foreign sites, while closing or scaling down activities or not expanding at home for expansion abroad".

Veugelers (2005) distinguishes two basic mechanisms of delocalisation and its course:

1) offshoring - relocation of economic activities via establishment of a subsidiary or company abroad (connected with FDI in the foreign region) where the production chain remains in exclusive possession of the relocating company.

2) outsourcing - transfer of economic activities abroad by engaging foreign suppliers (subcontracting).

The classification of delocalisation according to the share of transferred activities and potential impacts on the economy of host regions is the key factor for regional policy. According to the first criterion, Mariotti (2005) distinguishes:

a) Integral delocalisation - transfer of all economic activities to another locality simultaneously followed by closure of facilities in the former locality.

b) Partial delocalisation / transfer of a part of activities to another region followed by keeping of the former facility.

Integral delocalisation "without compensation" has usually negative impacts and can lead to the so-called absolute deindustrialization associated with decrease of employment, production and productivity in the manufacturing industry. Partial delocalization is a natural, usually long-term beneficial process of shifting sources and employment from low value added activities (assemblage) to higher value added activities. This article deals solely with the integral delocalisation, which is understood as a (potential) threat of economic growth and jobs in the Czech Republic or some of its regions.

The predisposition of manufacturing industry towards delocalisation is a result of operation of three factor groups - the so called push-factors, pull-factors and keep-factors of delocalisation (van Dijk, Pellenbarg, 1999).

Push-factors are motives leading firms to leave their locality (Pen, 1999). They represent a set of regional comparative disadvantages forcing firms to delocalise.

Pull-factors comprise comparative advantages of potential target regions for delocalisation. Considering operation of push- and pull-factors, it is possible to categorize the delocalisation, by the prevailing motives of companies' displacement as cost oriented (most often driven by labour costs reduction), market oriented (capturing 
new markets), and resource oriented (qualified labour force, suppliers, mineral resources, etc.)

Keep-factors favour firm continuance in the current location. Configuration of keep-factors is crucial for analysis of manufacturing predispositions towards delocalisation. There are two main reasons:

1) The scope and nature of keep-factors determines financial and organisational intensity of the possible delocalisation. It is impossible to find out which firms (industries) are most likely to delocalise manufacturing activities. Nevertheless, it is possible to reveal which firms are able to delocalise easily, and for which firms the delocalisation poses a significant complication.

2) Keep-factors are shaped at the company, local and regional level. Therefore, the keep-factors of a specific company can be roughly identified and quantified in the regional context. On the other hand, push and pull-factors are influenced mainly by global political (free goods and capital flows) and economic conditions (global competitiveness intensity, development of production factors costs, trends in $\mathrm{R} \& \mathrm{D}$, technology and organisation).

Keep-factors can be divided into two groups - internal (intra-firm) and external (firm's dependencies on the external environment). Characteristics of production chain, especially capital and technological intensity (e.g. Pennings, Sleuwaegen, 2000; Tiggeloove, Vossen, 2005), and complexity of value chain, given by the share of managing function and sophisticated manufacturing and non-manufacturing activities (Gorter, Nijkamp, 2002; Meijboom, Voordijk, 2003), have crucial influence on the probability of delocalisation. Firm's dependency on regional institutions is the key external factor (e.g. Breschi, Lissoni, 2001). Among the most important external factors are also relations with the suppliers, dissemination of innovations and dependencies on $\mathrm{R} \& \mathrm{D}$ sector. Beside the regional embeddedness, the delocalisation is also influenced by operating features of the host region (its geographical position, traffic accessibility, supply and price of production factors, political stability and macroeconomic environment).

The following statistical analysis of delocalisation of manufacturing companies is based on quantification of the most important internal keep-factors - the capital intensity of production process, the value chain complexity and the sophistication of production operations.

The capital intensity is defined as a share of fixed assets in number of employees in FTE (Pennings, Sleuwaegen, 2002b). High capital expenditures increase the share of sunk costs on tangible assets (Caves, Porter, 1976; Pennings, Sleuwaegen, 2000; Stam, 2003). Sunk costs can be defined as firms expenses that "are tightly connected with individual usage and are not recoverable in a case of firms closure" (Mata, 1991, p. 5). Investments into buildings, purchases of machinery or training of employees are the typical example of sunk costs. The immobility of capital is a key factor of geographical inertia of manufacturing industry.

Reduction of labour costs is the most frequent delocalisation motive of production activities to low-costs countries (Antras, Helpman, 2004; Tiggeloove, Vossen, 2005). Firms in capital-intensive industries are not highly motivated to relocate in order to decrease labour costs because their competitive advantage is not based on this factor. 
Investment into fixed assets is the important aspect of regional embeddedness (Bruinsma, Gorter, Nijkamp, 1998).

Assessment of the value chain complexity distinguishes companies that just acquire and process resources or components (they perform simple production activities), and companies doing other strategically important activities as well, like product design, marketing, logistics or after sale services (Kadeřábková, 2005). Subsidiaries without higher production and non-production functions are the most likely to delocalise (Brouwer, 2004; Bruinsma, Gorter, Nijkamp, 2002). On the other hand, presence of managing functions, technology-intensive activities, research and development, marketing and other strategic activities deepen the regional embeddedness, strengthen the location inertia and increase the firms localisation demands, since the group of potential target regions able to offer suitable firms requirements is narrowing.

Sophistication and technological intensity of production techniques are closely related to the value chain complexity factor and influence the location stability in three ways:

1) They increase and specify localisation requirements of production activities. Crucial is the supply of qualitative factors in a target region, namely availability of highly qualified human resources (researchers and technicians), the quality of R\&D institutions, the intensity of cooperation between companies and R\&D institutions, and other factors (Kadeřábková, 2005).

2) They are connected with intensive dependencies on actors and institutions in domestic region. The inertia arising in stability of long-term dependencies on suppliers, $R \& D$ institutions and other regional actors can be considered as the key keep-factor (Brouwer, 2004).

3) They increase the technological, organisational and financial intensity of delocalisation (Baaij, 2005). In the context of international organisation of production process, the key factor of the manufacturing industry mobility is the degree of technological standardisation and codifiability of production processes which leads to routinisation of employee activities. Routinesed activities (manual as well as cognitive) can be most easily delocalised, because they are based on codified knowledge and allow management and controlling activities at the international level, without personal contact (Autor, Levy, Murname, 2003). Moreover, routine activities include whole spectrum of qualification levels, therefore, jobs requiring university degrees can be delocalised as well (Antras, Garicano, Rossi-Hansberg, 2006; Bronfenbrenner, Luce, 2004).

External keep-factors have not been included into the statistical analysis because of low accessibility of the data and quantification difficulties. The analysis of regional dependencies requires individual research at the level of individual firms and regions.

\section{Data and Methodology}

The identification of regions with concentration of assembly activities is based on statistical analysis of a data set of 796 companies with 100 or more employees in technology-intensive branches of manufacturing industry. The assessment of company localisation stability is based on three economic indicators representing the above mentioned internal keep-factors (see Table 1). 
Table 1

Indicators of Company Location Stability in the Manufacturing Industry

\begin{tabular}{|l|l|l|l|}
\hline $\begin{array}{l}\text { Keep-factors } \\
\text { groups }\end{array}$ & Indicator & $\begin{array}{l}\text { Indicator } \\
\text { abbreviation }\end{array}$ & Unit \\
\hline Capital intensity & Sunk fixed assets* per employee & SUNK & CZK thousand \\
\hline $\begin{array}{l}\text { Complexity of } \\
\text { value chain }\end{array}$ & Value added per employee & VA & CZK thousand \\
\hline $\begin{array}{l}\text { Sophistication of } \\
\text { production } \\
\text { processes }\end{array}$ & $\begin{array}{l}\text { The share of R\&D employees in } \\
\text { the whole number of company } \\
\text { employees }\end{array}$ & R\&D & $\%$ \\
\hline
\end{tabular}

* Sunk fixed assets = financial value of buildings and, machinery equipment.

Source: own construction

The indicator VA reflects the productivity, competitiveness and the level of value added created in host region. Low values indicate production units based on assemblage characterised by high import and re-exports of assembled components, and therefore absence of higher productive and non-productive functions generating high added value. The indicator of the share of value added on outputs can be used alternatively. Nevertheless, this indicator is highly influenced by labour costs and technological features of particular industries. Therefore, this indicator is not unambiguous.

The goal of this article is to determine whether low capital-intensive firms, showing low productivity and low level of $R \& D$ activities, tend to be localised in economically lagging regions which are attractive for costs seeking FDI because of higher unemployment rate, availability of investment incentives and lower level of real estate prices. In the Czech Republic, there are three legislatively defined types of regions with concentrated state support (see the Strategy of Regional Development of the Czech Republic). Following regions are defined according to the characteristic of labour market, tax incomes, number of entrepreneurs and purchasing power of inhabitants (see Figure 1):

Economically weak regions (usually rural periphery) - low economic performance, wages and economic activity, high unemployment rate, unfavourable geographical location and underdeveloped technological infrastructure.

Structurally affected regions - high share of mining and heavy industries, unqualified labour force, high unemployment rate, damaged environment.

High unemployment regions - combination of the former two types.

Hampl $(2001,2005)$ considers the position of micro-regional centres in the settlement hierarchy, macropositional attractiveness (in the sense of the proximity of Bavarian borders and Prague) and inherited economic specialisation as the key factors influencing the achieved level of economy. He distinguishes two types of economically developed regions:

Prague - the core highly exceeds economy of the other regions, high concentration of quarternary activities, qualified labour force, FDI gateway city and growth pole (Dostál, 2008; Viturka, 2007). 
Mezo-regional centres - relatively heterogeneous group including more or less successful centres concentrating progressive economic activities, universities and qualified labour force. Mezo-regional centres with high unemployment rate and inherited specialisation in mining and heavy industries have been included in the group of structurally affected regions and high unemployment regions. (Ostrava, Ústí nad Labem). The new mezo-regional centre of Jihlava is included in this group for its exceptionally successful transformation.

In the regions with concentrated state support, characterised by the higher unemployment rate, certain investment incentives are implemented, such as lower limit of the minimal investment for the provision of investment incentives (CzechInvest, 2008). For the geographical definition of such regions see Figure 1.

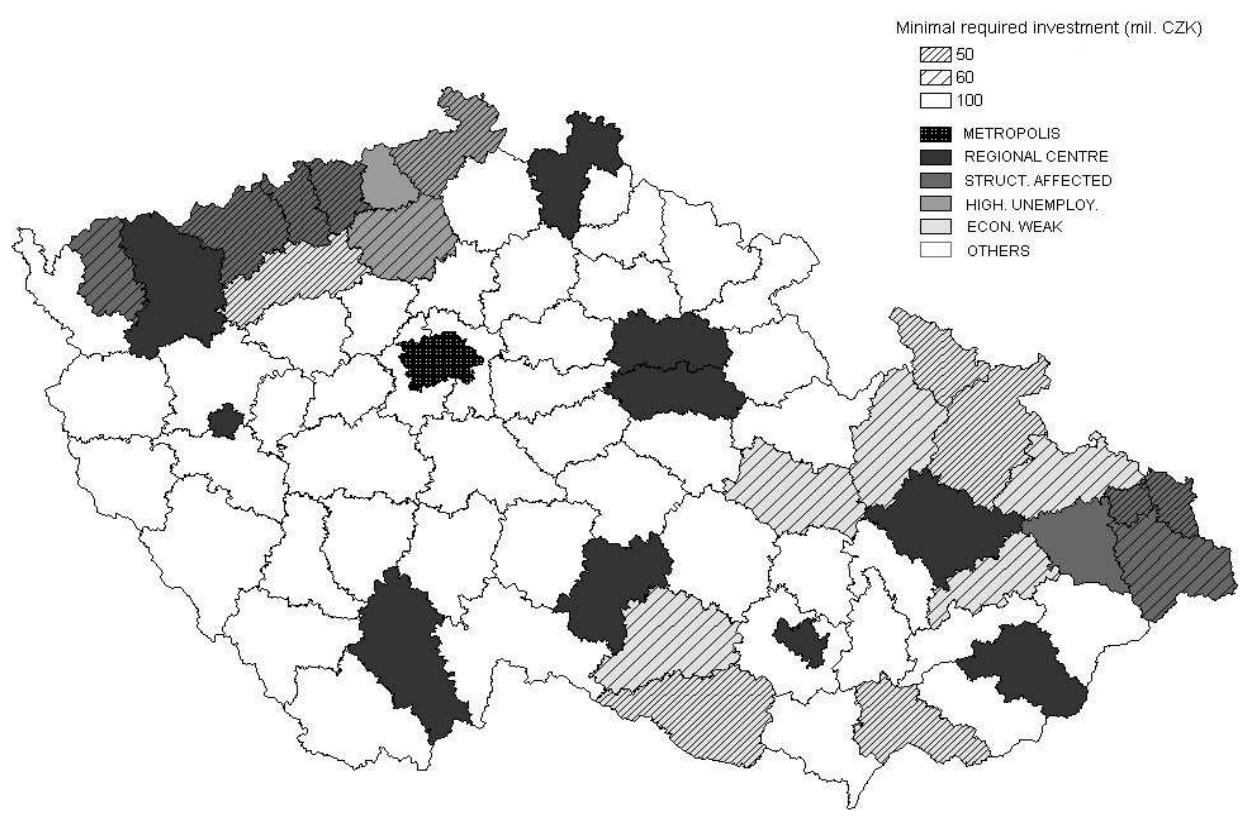

Source: Hampl, 2001, 2005; Strategy of Regional Development of the Czech Republic 2006; CzechInvest, 2008.

In all tables the statistical data and figures originate from the "Annual Survey of Economic Subjects in Selected Productive Industries in 2005" published by the Czech Statistical Office (Roční výkaz ekonomických subjektů vybraných produkčních odvětví za rok 2005 -http://dw.czso.cz/pls/vykazy/pdf111?xvyk=971\&cd=0) if not stated otherwise. Statistical data of the Czech Statistical Office are related to year 2004.

This data source provides comprehensive list of Czech manufacturing firms with 100 or more employees - for each firm balance-sheet and income statement are 
available. Financial indicators are supplemented by employment characteristics and number of R\&D workers.

Therefore, our analysis is based on individual data, which have been aggregated to the microregional level (districts) to compare different types of microregions. The database is not public available (protection of firm data), so the aggregation of three used indicators was made by employees of Ministry of Industry and Trade.

First, the database of all 796 firms has been prepared - five indicators for each firm (number of employees, output, value added, sunk fixed assets, number of R\&D workers). Three ratio indicators were computed from these basic indicators - capital intensity, productivity (value added per employee) and R\&D intensity. These indicators were calculated for each firm and also for the particular regional types.

Second, the database of all firms was in successive steps divided into quartiles of capital intensity, productivity and $R \& D$ intensity. Then we aggregated the employment of firms in particular quartiles to the microregional level and calculated the share of the $1^{\text {st }}, 2^{\text {nd }}, 3^{\text {rd }}$ and $4^{\text {th }}$ quartile in employment of every single district.

\section{Results}

We expected the technology-intensive industries to be concentrated in metropolitan areas and regional centres because they are characterised by progressive structure of economy, high economic efficiency, quality of human resources and high level of concentration of R\&D activities and sophisticated manufacturing activities inherited from the era of socialism. However, approximately $50 \%$ of jobs, value of production, value-added and R\&D personnel is concentrated in a group of regions labelled "others" in the Table 2.

Table 2

Distribution of Technology-Intensive Industries by Regional Type in 2004

\begin{tabular}{|l|c|r|r|r|r|r|r|}
\hline TYPE OF REGION & ENTER & EMPLOY & OUTPUT & VA & SUNK & $\begin{array}{c}\text { R\&D } \\
\text { EMPL }\end{array}$ & $\begin{array}{c}\text { TOTAL } \\
\text { EMPL }\end{array}$ \\
\hline METROPOLIS & 8,8 & 6,6 & 5,5 & 8,4 & 5,3 & 13,5 & 13,5 \\
\hline REG. CENTRE & 23,1 & 22,5 & 21,4 & 20,4 & 18,2 & 19,7 & 18,5 \\
\hline ECON. WEAK & 8,8 & 8,6 & 5,7 & 7,8 & 7,3 & 5,8 & 10,5 \\
\hline STR. AFFECTED & 11,1 & 11,9 & 10,9 & 12,7 & 14,5 & 8,1 & 12,6 \\
\hline HIGH UNEMPLOY. & 2,4 & 2,2 & 1,7 & 1,8 & 2,9 & 1,0 & 3,4 \\
\hline OTHERS & 45,8 & 48,2 & 54,8 & 48,9 & 51,8 & 51,8 & 41,5 \\
\hline CZECH REP. & 793 & 336577 & 948,1 & 204,9 & 402,8 & 7742 & 4872356 \\
\hline
\end{tabular}

Notes: $E N T E R=$ Number of enterprises, EMPLOY=employment in HT and MHT manufacturing, VA= value added, SUNK = sunk fixed assets, R\&D EMPL= number of R\&D workers, TOTAL EMPL= total employment (all economic sectors).

Source: Ministry of Industry and Trade 2006; Czech Statistical Office 2006

The group of "other regions" is internally very heterogeneous in terms of localisation stability indicators, the branch structure of the manufacturing, the amount of incentive investment and the total stock of FDI. This group includes important industrial regions whose economic bases are supported by one or a few major investors 
(Mladá Boleslav, Kolín, Ustí nad Orlicí) as well as economically relatively marginal regions of Southern Bohemia, Central and Southern Moravia. A common feature of "other regions" is the fact that they were not affected by massive development of heavy industry during the era of socialism, but were rather specialized in the automotive, engineering, electrical as well as traditional textile and food industries.

Diversified economy and workforce qualification in these regions have attracted a large amount of incentive FDI ( $47 \%$ of the volume of the Czech Republic) in the form of greenfield as well as brownfield investments. The majority of FDI has been absorbed by the automotive industry with two major car manufacturers (Škoda-Auto in Mladá Boleslav and TPCA in Kolín) and a dense network of subcontractors (Pavlínek, Janák, 2007). The second most attractive branch for FDI has been the electrical industry (Čadil, 2007).

The share of regional centres and "other regions" in the total amount of jobs in technology-intensive industries is bigger than their share in total employment in the Czech Republic. Prague, as a tertiarised metropolis, represents the opposite case. However, importance of Prague is in the concentration of corporate headquarters and $R \& D$ centres. The group of regions with concentrated state support is generally characterized by lower productivity and R\&D intensity of manufacturing companies. Nevertheless, the differences between these and other regions are not significant. This indicates a large internal heterogeneity of technology-intensive industries in all types of regions. High productivity and capital intensity in the case of structurally affected regions results from a significant concentration of heavy industry - manufacturing of basic chemicals (see Table 3).

Internal heterogeneity of technology-intensive industries in terms of location stability is documented by Figures 3, 4, 5 and Table 3. The map of capital intensity shows evident concentration of companies with low capital intensity in the group of "other regions" (47.3\%). The highest share of employment is reached in the heterogeneous group of districts in Plzeňský and Karlovarský region near the German border, which are followed by structurally affected and economically weak districts of northern Bohemia, southern and northern Moravia. Only $25.5 \%$ of jobs in the $4^{\text {th }}$ quartile are located in districts with the concentrated state support. The $3^{\text {rd }}$ and $4^{\text {th }}$ quartile provides $38.3 \%$ of jobs in technology-intensive industries for this group of regions. Interestingly, the distribution of employment is very similar as in the case of productivity indicators, according to quartiles of capital intensity and types of regions (see Table 3).

We identified two big clusters of capital-intensive companies. The first is in the north-western part of Central Bohemia (other microregions) with surrounding districts of Ústecký region (mostly structural-affected). High capital intensity in these regions is caused by inherited base of heavy industries (basic chemicals) and higher investment incentives provided to reduce the high structural unemployment in this type of regions. The second cluster consists of districts in the north-eastern part of Moravia, including the regions categorized as "others", "structurally affected" and "high unemployment". These regions can be characterized by combined influence of investment incentives and traditionally strong engineering and electrical engineering production. In addition, high capital intensity is also typical for districts with large enterprises in the automotive industry (Mladá Boleslav, Jičín, Jihlava, etc.) 
Regional productivity factor levels significantly correlate with the localization of capital-intensive industries. Firms with more capital-intensive production report higher productivity even in structurally affected and economically weak regions. Compared to the map of capital intensity, the influence of regional centres and metropolitan area is increased. Portion of firms with lower productivity $\left(3^{\text {rd }}, 4^{\text {th }}\right.$ quartile $)$ in employment varies between $30-40 \%$ in all types of districts (with the exception of more than half the share in the economically weak districts - Table 3)

Table 3

Employment in Technology-Intensive Industries according to Types of Regions and Quartiles of Productivity in 2004

\begin{tabular}{|l|c|c|c|c|c|}
\hline TYPE OF REGION & $\mathbf{1 Q}$ & $\mathbf{2 Q}$ & $\mathbf{3 Q}$ & 4Q & TOTAL \\
\hline METROPOLIS & 10479 & 4425 & 4546 & 2863 & 22313 \\
\hline REG. CENTRE & 20060 & 25267 & 17656 & 12696 & 75679 \\
\hline ECON. WEAK & 8008 & 5212 & 10905 & 4712 & 28837 \\
\hline STR. AFFECTED & 14505 & 11942 & 9530 & 3970 & 39947 \\
\hline HIGH UNEMPLOY. & 1980 & 2674 & 1631 & 1185 & 7470 \\
\hline OTHERS & 68013 & 38189 & 26498 & 29631 & 162331 \\
\hline CZECH REPUBLIC & 123045 & 87709 & 70766 & 55057 & 336577 \\
\hline
\end{tabular}

Notes: $1 \mathrm{Q}, 2 \mathrm{Q}, 3 \mathrm{Q}, 4 \mathrm{Q}=1 \mathrm{st}, 2 \mathrm{nd}, 3 \mathrm{rd}, 4$ th quartile (the highest productivity is in $1 \mathrm{Q}$, the lowest in $4 \mathrm{Q}$ ).

Source: Ministry of Industry and Trade 2006; Czech Statistical Office 2006

Indicator of $\mathrm{R} \& \mathrm{D}$ intensity has quite different geographical distribution. Nevertheless, R\&D activities are again localized in all categories of regions. The dominance of "others" is weakened by the strong position of metropolis and some regional centres. Regions with higher percentage of R\&D personnel do not always reach the high labour productivity and capital intensity and vice versa, concentration of capital-intensive industries in structurally affected districts is not always accompanied by the presence of $R \& D$ activities.

There is a strong path-dependency in the localization of corporate R\&D centres, which correspond to the regional distribution of large manufacturing enterprises (automotive industry in Mladá Boleslav or Jihlava, engineering in Nový Jičín, machinery and electric equipment in Blansko, etc.) in the era of socialism. The level of R\&D intensity is also positively influenced by the concentration of universities and $\mathrm{R} \& \mathrm{D}$ institutions in the metropolitan region and regional centres. However, the impact of the incentive investment and FDI is generally weak.

Foreign firms localize their R\&D activities either in the immediate vicinity of production units in order to encourage manufacturing activities such as form of adaptation technology, or in the capital and regional centres, where they use strong local R\&D potential (Čadil, 2007). In the latter case, the main location factors are sufficient skilled labour, industrial tradition, advanced technology and quality of local R\&D infrastructure (Čadil, Kučera, Pazour et al., 2007). 


\section{Conclusions}

This article attempts to identify regions concentrating firms with low capital intensity, productivity and $R \& D$ intensity within technology-intensive branches in manufacturing industry, thus firms focused on simple production or assembly activities without more important linkages in the host region. These "footloose" firms are attracted especially by the reduction of labour costs and utilisation of investment incentives and can be localised nearly anywhere. Increasing wages and other costs and future cancellation of investment incentives will eventually exclude the Czech Republic from the group of low-costs countries. The strengthening competition of the new EU member states (Romania and Bulgaria), Eastern Europe and Asian low-costs countries bring the threat of deindustrialisation and delocalisation without compensations. The negative impacts could be especially destructive in regions characterised by high employment in assembly activities of large foreign MNEs.

This article answers the question whether these firms were geographically concentrated in the most vulnerable economically lagging regions of the Czech Republic including rural periphery as well as the old industrial districts with the high unemployment rate. The main findings relating to localisation pattern of technologically intensive branches in the Czech Republic and especially assembly activities can be summarised in following points:

1) The localisation of technology-intensive branches of the manufacturing industry in the Czech Republic corresponds neither to the settlement hierarchy nor to the economic performance of regions. The low ratio of the metropolis (Prague) and regional centres, in comparison with the dominating category of other districts, results from two factors:

- Impact of socialist distribution of technology-intensive branches and R\&D activities (mainly in automotive and electric industry) on regional transformation successfulness and FDI inflow into the group of "other regions".

- The heterogeneity of localisation stability factors of the Czech technology-intensive branches - part of FDI was used for setting up assembly activities in regions with higher unemployment and accessibility of investment incentives, or rural districts with favourable geo-economic location. (e.g. Tachov, Pilsen-north, etc.)

2) Regional differences of localisation stability indicators are a consequence of:

- Branch structure of industrial production and qualification of labour force inherited from the socialist era. In general, the value of the majority of localisation stability indicators is mostly influenced by historical geographical distribution of large companies in automotive industry (Mladá Boleslav, Jičín, Jihlava, etc.). Regarding productivity and capital intensity, these indicators are further influenced by geographical concentration of heavy industries (basically chemistry) in Central Bohemia and Ústecký region. The geographical distribution of R\&D activities is determined (except of automotive industry) by localisation of companies operating in engineering and electric industry (Blansko, Nový Jičín).

- The regional accessibility of investment incentives has higher impact on localisation of technology centres than on localisation of assembly activities in high unemployment districts.

3) Localisation of firms with the low value of localisation stability indicators $\left(3^{\text {rd }}\right.$ and $4^{\text {th }}$ quartile) is in accordance with the localisation pattern of firms operating in technologi- 
cally intensive branches. Nearly half of such firms is localized in "other regions". The hypothesis on concentration of internationally mobile firms in economically lagging districts with high unemployment and availability of investment incentives has not been confirmed. The group of "footloose" firms is mostly localised in Prague and various districts of Plzeňský and Karlovarský regions. The excessive localisation of the $3^{\text {rd }}$ and $4^{\text {th }}$ quartile firms in proximity of German borders indicates the intensive cross border cooperation caused by German firms sub-contracting their assembly activities.

4) The share of the $3^{\text {rd }}$ and $4^{\text {th }}$ quartile firms on employment varies between $30 \%$ and $40 \%$ in all explored district groups. This means that economically lagging regions are not characterised by less favourable structure of technologically intensive branches in comparison with metropolis and regional centres. Firms in districts with high unemployment and economically weak districts show lower productivity, share of value added on outputs, and R\&D intensity. Structurally affected districts reach relatively high capital intensity and productivity resulting from the long-term specialisation on heavy industries.

5) All groups of regions, including the metropolis and regional centres, are significantly internally differentiated according to indicators of localisation stability. In addition, variation between individual groups is even higher then within them. In many cases, assembly activities are localised in important industrial cities, although these cities are attractive for technology centres as well. In the group of economically lagging districts, the district of Opava has significantly exceeded the average values. Similarly, Nový Jičín specialised in automotive and electric industries reached an outstanding position among structurally affected districts. Both districts have localised important R\&D centres.

Firms characterised by low capital intensity, productivity and R\&D intensity, being considered the most predisposed to delocalisation, are geographically dispersed in all types of regions in the Czech Republic. Czech companies, which have been becoming suppliers of standardised components for foreign countries, as well as greenfield FDI in export oriented assembly capacities, are represented in this group of firms. As far as the deindustrialisation and unemployment growth are concerned, geographical dispersion of this type of firms is good news for the regional policy of the Czech Republic.

\section{References}

Agnew, J., Knox, P. (1998), The Geography of the World Economy. London: Arnold.

Antras, P., Garicano, L., Rossi-Hansberg, E. (2006), "Offshoring in a Knowledge Economy." The Quarterly Journal of Economics, Vol. 121, No. 1, pp. 31-77.

Antras, P., Helpman, E. (2004), "Global Sourcing." Journal of Political Economy, Vol. 112, pp. 552-580.

Autor, D. H., Levy, F., Murname, R. (2003), "The Skill Content of Recent Technological Change: An Empirical Exploration." Quarterly Journal of Economics, Vol. 68, pp. 1279-1334.

Baaij, M. et al.. (2005), "Relocating Corporate HQ." Business Strategy Review. 2005, pp. 45-48.

Bell, D. (1973), The Comming of Post-Industrial Society: A Venture in Social Forecasting. Nex York: Basic Books.

Berry, B. B. J., Conkling, E. C., Ray, D. M. (1997), The Global Economy in Transition, 2. ed., Upper Saddle River: Prentice Hall.

Blažek, J., Uhlíř, D. (2002), Teorie regionálního rozvoje. Praha: Karolinum, 211 p.

Blinder, A. (2006), „Offshoring: The Next Industrial Revolution.” Foreign Affairs, Vol. 85, No. 2, pp. 113-128. 
Breschi, F., Lissoni, S. (2001), "Knowledge Spillovers and Local Innovation Systems: A Critical Survey." Presented at the European Regional Science Association Conference, Barcelona.

Bronfenbrenner, K., Luce, S. (2004), „The Changing Nature of Corporate Global Restructuring: The Impact of Production Shifts on Jobs in the US, China and Around the Globe." Washington: The US-China Economic and Security Review Commission.

Brouwer, A. E. (2005), Old Firms in the Netherlands: the Long-term Spatial Impact of Firms' Identities and Embeddedness, Groningen: University of Groningen.

Brouwer, A. E., Mariotti, I., Van Ommeren, J. N. (2004), "The Firm Relocation Decision: An Empirical Investigation." The Annals of Regional Science, Vol. 38, pp. 335-347.

Brouwer, A. E. (2004), "The Inert Firm, Why Old Firms Show a Stickiness to Their Location." Presented at the 44th European Regional Science Association conference 'Regions and Fiscal Federalism', Porto.

Bruinsma, F., Gorter, C., Nijkamp, P. (2002), "Nomadic Firms in a Globalizing Economy" Discussion Paper No. TI 98-120/3. Amsterdam: Tinbergen Institute.

Caves, R., Porter, M. (1977), "From Entry Barriers to Mobility Barriers: Conjectual Decisions and Contrived Deterrence to New Competition." Quarterly Journal of Economics, Vol. 91, pp. 241-261.

Carlin et al., (1997), "Quantifying a Dangerous Obsession? Competitiveness and Export Performance in an OECD Panel of Industries. "Discussion Paper 9, London: Centre for Economic Performance.

Clark, G. L., Wrigley, N. (1997), "Exit, the Firm and Sunk Costs: Reconceptualizing the Corporate Geography of Disinvestment and Plant Closure." Progress in Human Geography, Vol. 21, pp. 338-358.

Cooke, P., Morgan, K. (1994), "The Regional Innovation System of Baden-Württemberg." International Journal of Technology Management, Vol. 9, pp. 394-420.

Coucke, K., Pennings, E., Sleuwaegen, L. (2005), "Employee Lay-off under Different Modes of Restructuring." Working Paper. Gent: Vlerick Leuven Gent Management School, 29 p.

Čadil, V. (2007), "Restrukturalizace průmyslu v České republice po roce 1989 a vliv přímých zahraničních investic. (Restructuring of Manufacturing Industry in the Czech Republic since 1989 and the Influence of FDI.)" PhD thesis. Prague: Faculty of Science, Charles University in Prague. 174 p.

Čadil, V., Kučera, Z., Pazour, M. et al. (2007), "Localisation Motives for Research and Development Investment of Multinational Enterprises, European Trends and Situation in the New Member States." Prague: TC AS CR. 64 p.

Damijan, J. P., Rojec, M. (2005), "Relocation via Foreign Direct Investment from Old to New Member States." Presented at conference Re-location of Production and Jobs to CEE Countries - Who Gains and Who Loses? Wien.

Daudin, G., Lavasseur, S. (2005), "Competition from Emerging Countries, International Relocations and their Impact on Employment." Working Paper. Nice: University of Nice Sophia Antipolis.

De Clercq, M., Verbeke, T. (2003), "Environmental Policy Uncertainty, Policy Coordination and Relocation Decisions." Working Paper. Gent: Faculty of Economics and Business Administration.

Dicken, P. (2003), Global Shift: Reshaping the Global Economic Map in the 21st Century, London: Sage. 632 p.

Dijk, J. Van, Pellenbarg, P. H. (1999), Demography of Firms, Spatial Dynamics of Firm Behaviour, Utrecht/Groningen: KNAG/FRW RUG. 262 .

Dostál, P. (2008), "The Post-Communist Capital City Effects, Transactional Activities and Regional Development in the Czech Republic in the 1990s." In: Strubelt. W. and Gorzelak, G. (eds.) City and Region. Papers in Honour of Jiri Musil. Opladen, Burdich UniPress, pp. 15-42.

Ericksson, R. A. (1987), "Profit Cycles, Oligopoly and Regional Development: A Commentary." Urban Geography, No. 8, pp. 174-179.

Gaffard, J. L., Quéré, M. (2005), “Relocation: What Matters? Competition or/and Co-ordination.” Paper presented at the $2^{\text {nd }}$ Euroframe Conference on Economic Policy Issues in the European Union, Vienna.

Geishecker, I. (2005), "Does Outsourcing to CEE Really Threaten Manual Workers' Jobs in Germany?" Working Paper. Hamburg: Hamburg Institute of International Economics. Hall 1988.

Hampl, M. (2005), Geographical Organization of Czech Society: Transformation Processes and Their General Context. Prague: DemoArt. 147 p. ISBN 80-86746-02-X.

Hampl, M. (2001), Regional Development: Specific Features of the Czech Transformation, European Integration and General theory. Prague: Charles University, Faculty of Science. 328 p. 
Hayter, R. (2004), The Dynamics of Industrial Location, the Factory, the Firm and the Production System. New York: John Wiley \& Sons.

Kadeřábková, A. (2007a), "Technologická náročnost a zahraniční investice v konkurenční výhodě ČR.“ Politická ekonomie, 55 (3), pp. 354-373.

Kadeřábková, A. (2007b), "Structural Characteristics of Competitiveness of Czech Economy. Working Paper CES VŠEM, no. 4., 59 p.

Kadeřábková, A. (2005), "Comparative Advantage of the Czech Economy in High-tech Activities." Bulletin CES VŠEM, No. 6, pp. 1-5.

Levy, F., Murname, R. (2004), The New Division of Labor: How Computers Are Creating the Next Job Market. Princeton: Princeton University Press.

Lexa, J., Rojíček, M. (2007), "Branch knowledge-intensity and Competitiveness of the Czech Economics." Working Paper CES VŠEM No. 10, 80 p.

Lipietz, A. (1992), "The Regulation Approach and Capitalist Crisis: an Alternative Compromise for the 1990s." In: Dunford, M., Kafkalas, G. (eds.), Cities and Regions in the New Europe. London: Belhaven, pp. 309-334.

Marin, D. (2004), "A Nation of Poets and Thinkers - Less So with Eastern Enlargement? Austria and Germany." Discussion Paper No. 3526. London: Centre for Economic Policy Research.

Mariotti, I. (2005), Firm Relocation and Regional Policy. Groningen: Groningen University. 278 p.

Mata, J. (1991), "Sunk Costs and Entry by Small and Large Plants." In Geroski, P. A., Schwalbach, J. (eds.). Entry and Market Contestability: an International Comparison. Oxford: Blackwell, pp. 49-62.

Meijboom, B. R., Voordijk, J. T. (2003), "International Operations and Location Decisions: A Firm Level Approach." Journal of Economic and Social Geography TESG, Vol. 94, No. 4, pp. 463-476.

MPO (2006), "Delocalisation Risk in Czech Manufacturing industries." Working paper of Ministry of Industry and Commerce of the Czech Republic. Prague: Ministry of Industry and Commerce of the Czech Republic.

OECD (2005): Science, Technology and Industry Scoreboard. Paris.

Pavlínek, P., Janák, L. (2007), "Regional Restructuring of the Škoda Auto Supplier Network in the Czech Republic." European Urban and Regional Studies, Vol. 14, No. 2, pp. 133-155.

Pavlínek, P. (2003) "Transformation of the Czech Automotive Components Industry through Foreign Direct Investment." Eurasian Geography and Economics, Vol. 44, No. 3, pp. 184-209.

Pellenbarg, P. H., Van Wissen, L., Van Dijk, J. (2002), "Firm Relocations: State of the Art and Research Prospects." Research Report No. 02D31. Groningen: Rijksuniversiteit Groningen, Research Institute SOM.

Pen, C. J. (1999), "Improving Behavioural Location Theory: Preliminary Results of a Written Questionnaire about Strategic Decision Making on Firm Relocations." Presented at the European Regional Science Association Congress, Dublin.

Pennings, E., Sleuwaegen, L. (2006), "International Relocation of Production. Where Do Firms Go?" Scottish Journal of Political Economy, Vol. 53, No. 4, pp. 430-447.

Pennings, E., Sleuwaegen, L. (2002a), "New Empirical Evidence on the International Relocation of Production." Working Paper. Rotterdam: Catholic University of Leuven and Erasmus University.

Pennings, E., Sleuwaegen, L. (2002b), "The Reorganization Decisions of Troubled Firms: Exit, Downscale or Relocate." Working Paper No. 2002-21. Gent: Vlerick Leuven Gent Management School.

Pennings, E., Sleuwaegen, L. (2000), "International Relocation: Firm and Industry Determinants." Economic Letters, Vol. 67, pp. 179-186.

Pennings, E., Sleuwaegen, L., Monmaerts, G. (2000), "Relocation, an Element of Industrial Dynamics." Synthesis Report. Brussels: Federal Planning Bureau.

Rojíček, M. (2007), "Structural Analysis of the Czech Economics." Working Paper CES VŠEM No. 3, 49 p.

Rojiček, M. (2006), "Competitiveness of Industries in the Czech Republic." Bulletin CES VŠEM No. 23, pp. 3-4.

Roony, D., Hearn, G., Ninan, A. (2005), Handbook on the Knowledge Economy. Cheltenham: Edward Edgar.

Stam, E. (2006), "Why Butterflies Don't Leave. Locational Evolution of Evolving Enterprise." Discussion Paper No. 2006-20. Utrecht: Max Planck Institute of Economics, Group for Entrepreneurship, Growth and Public Policy.

Szalavetz, A. (2007), "Structural Change and Structural Competitiveness." Working Paper 155. Budapest: IWE.

Szanyi, M. (2005), "Competitiveness and Industrial Renewal Through International Production Relocation." Workshop Paper. Hamburg: Hamburg Institute of International Economics.

Tiggeloove, N., Vossen, M. (2005), "Vision on Relocation." Research Paper No. 05BEB05. Hague: Ministry of Economic Affairs. 
Veugelers, R. (2005), "Delocalisation: Which Challenges for the EU Economy?” DG Economic and Financial Affairs, Brussels.

Viturka, M. (2007), "Konkurenceschopnost regionů a možnosti jejího hodnocení a stimulace." Politická ekonomie, 55 (5), pp. 637-658.

Ženka, J. (2008), "Riziko delokalizace zpracovatelského průmyslu - regionální aspekty. (Risk of Delocalization of Manufacturing Industry in Czechia: Regional Aspects.)" Geography - Journal of CGS, Vol. 113, No. 1, pp. 1-19.

Ženka, J. (2009), “Delokalizace zpracovatelského průmyslu ČR - komponentní analýza. (Delocalization of Czech Manufacturing - Component Analysis.)" Politická ekonomie, 57 (1), pp. 77-91.

\section{Internet and other sources}

CZECHINVEST 2008 - www.czechinvest.org

CZECH NATIONAL BANK - http://www.cnb.cZ

CZECH STATISTICAL OFFICE (2006), Annual statement of economic subjects in selected production branches in year 2005 (1.6. 2006)

EUROPEAN RESTRUCTURING MONITOR (2006), Fact Sheets - http://eurofound.europa.eu/emcc/ erm/index.php (15. 3. 2006)

THE STRATEGY OF REGIONAL DEVELOPMENT OF THE CZECH REPUBLIC, www.mmr.cZ/ strategie-regionalniho-rozvoje- ceske-republiky-pro-leta-2007-2013.

\section{APPENDIX:}

Figure 2

Administrative Map of the Czech Republic

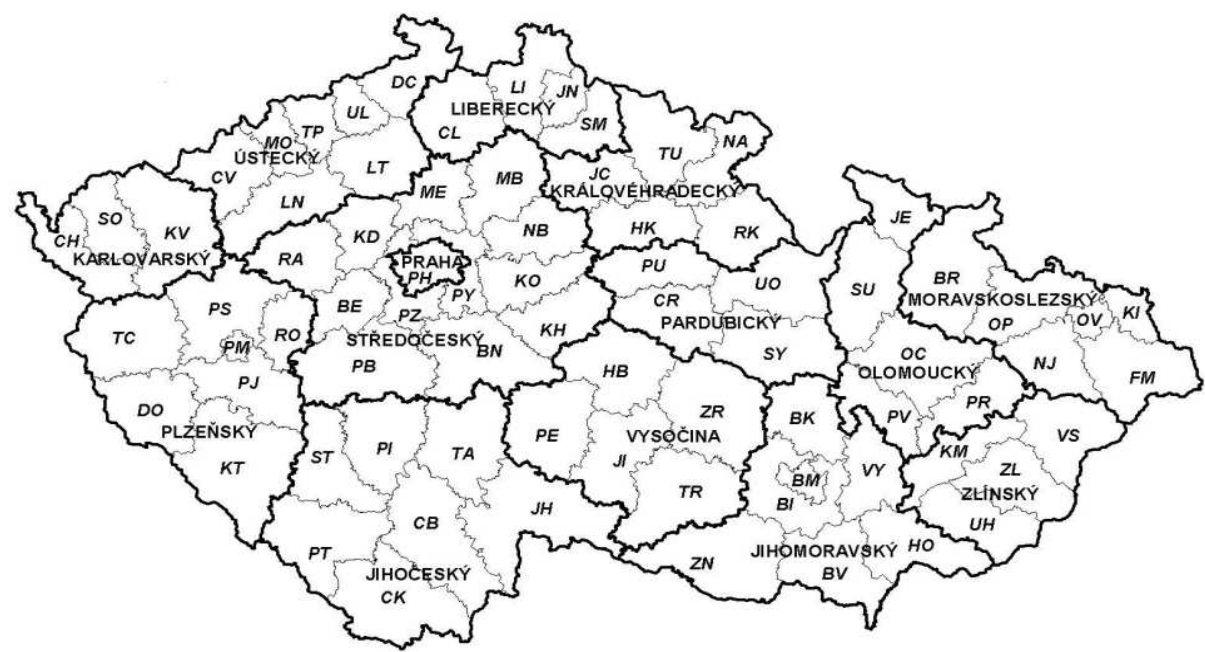

Notes: $\mathrm{CH}=\mathrm{Cheb}, \mathrm{SO}=$ Sokolov, $\mathrm{KV}=$ Karlovy Vary, TC=Tachov, DO=Domažlice, PS=Plzeň-sever,

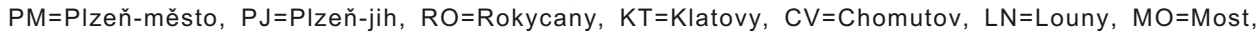

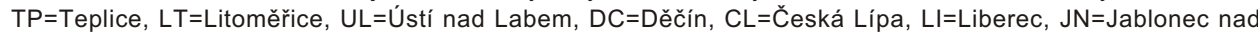
Nisou, $\mathrm{SM}=$ Semily, RA=Rakovník, $\mathrm{BE}=$ Beroun, $\mathrm{KD}=$ Kladno, $\mathrm{PB}=$ Přibram, ME=Mělník, PZ=Praha-západ, $\mathrm{PH}=$ Praha, $\mathrm{PY}=$ Praha-východ, $\mathrm{MB}=$ Mladá Boleslav, $\mathrm{NB}=$ Nymburk, $\mathrm{KO}=\mathrm{Kolín}, \mathrm{KH}=$ Kutná Hora, $\mathrm{BN}=$ Benešov, $\mathrm{ST}=$ Strakonice, $\mathrm{PT}=$ Prachatice, $\mathrm{PI}=\mathrm{Písek}, \mathrm{TA}=\mathrm{Tábor}, \mathrm{CB}=\mathrm{C}$ eské Budějovice, JH=Jindřichův Hradec,

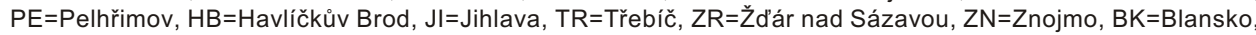

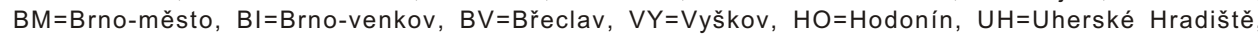
$\mathrm{KM}=$ Kroměřiž, $\mathrm{ZL}=\mathrm{Zlín}, \mathrm{VS}=\mathrm{Vsetín,} \mathrm{PV}=$ Přerov, $\mathrm{PR}=$ Prostějov, $\mathrm{OC}=$ Olomouc, $\mathrm{SU}=$ Šumperk, JE=Jeseník, $\mathrm{BR}=$ Bruntál, OP=Opava, $\mathrm{NJ}=$ Nový Jičín, OV=Ostrava, FM=Frýdek-Mistek, $\mathrm{KI}=$ Karviná.

Source: Czech Statistical Office 2008 
Figure 3

Regional Disparities in Capital Intensity of Technology-Intensive Industries in the Czech Republic (2004) - Employment in Quartiles of Capital Intensity

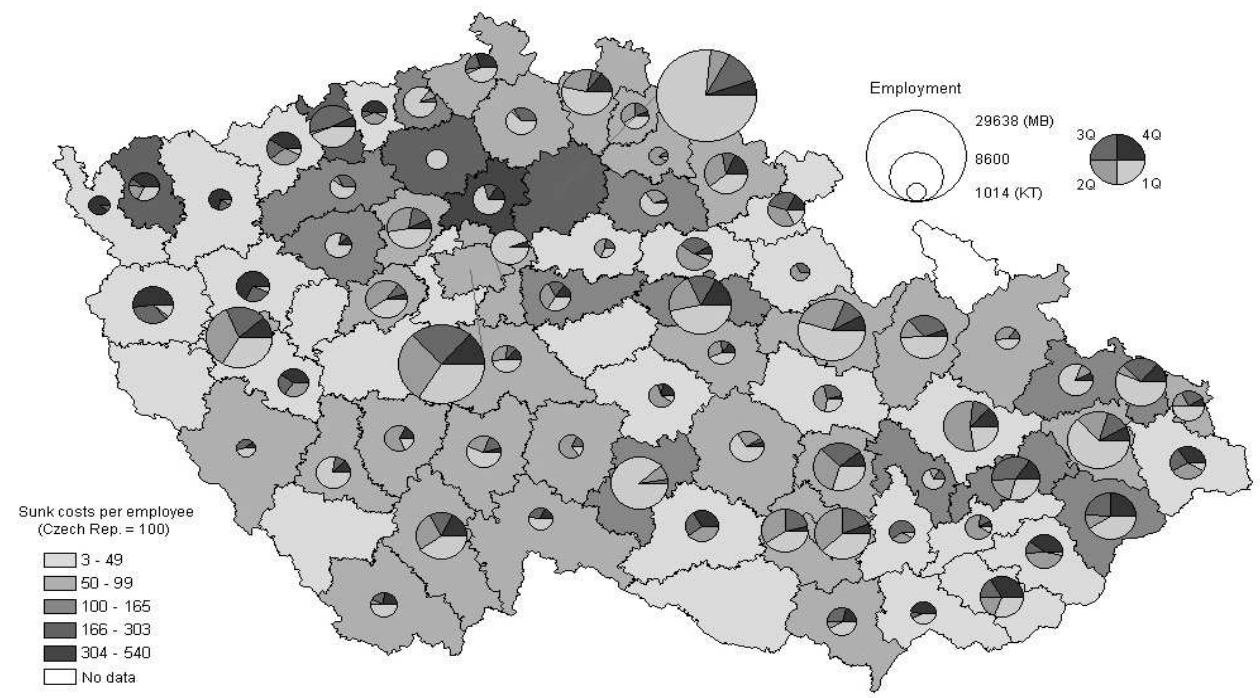

Notes: $1 \mathrm{Q}, 2 \mathrm{Q}, 3 \mathrm{Q}, 4 \mathrm{Q}=1^{\text {st }}, 2^{\text {nd }}, 3^{\text {rd }}, 4^{\text {th }}$ quartile (the highest capital intensity is in $1 \mathrm{Q}$, the lowest in $4 \mathrm{Q}$ ), districts with less than 1000 employees were neglected

Source: Ministry of Industry and Trade 2006

Figure 4

Regional Disparities in Productivity of Technology-Intensive Industries in the Czech Republic (2004) - Employment in Quartiles of Productivity

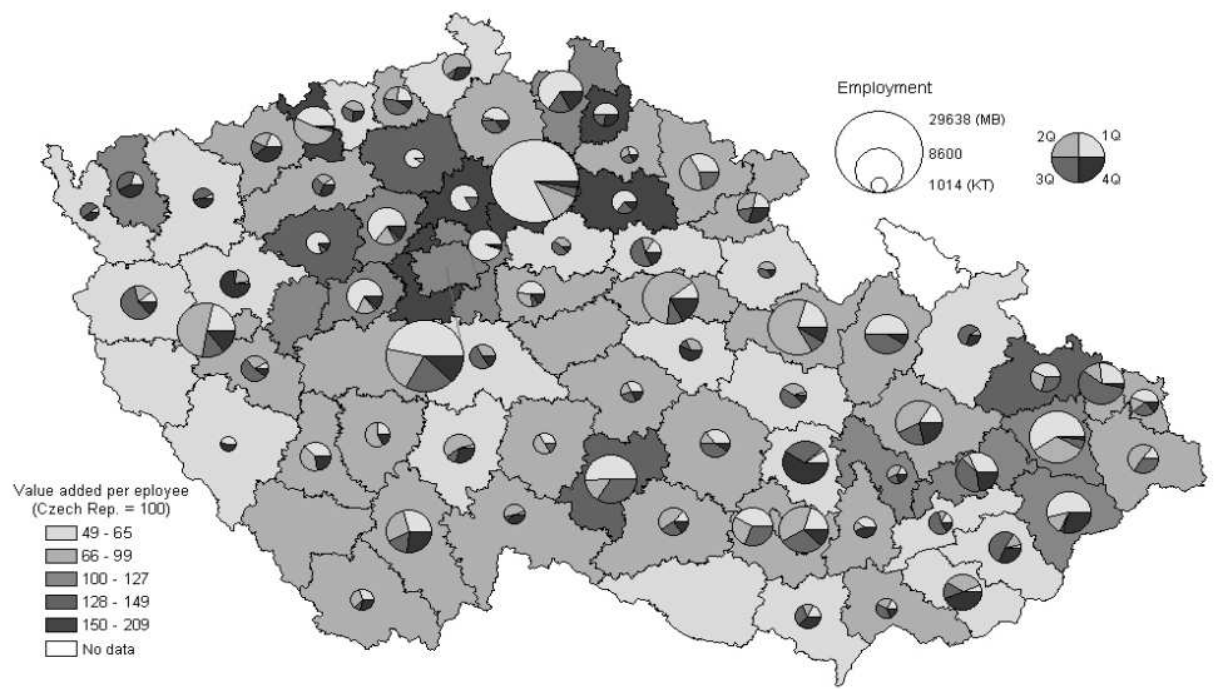

Notes: $1 \mathrm{Q}, 2 \mathrm{Q}, 3 \mathrm{Q}, 4 \mathrm{Q}=1^{\mathrm{st}}, 2^{\mathrm{nd}}, 3^{\mathrm{rd}}, 4^{\text {th }}$ quartile (the highest productivity is in $1 \mathrm{Q}$, the lowest in $4 \mathrm{Q}$ ), districts with less than 1000 employees were neglected.

Source: Ministry of Industry and Trade 2006 
Figure 5

Regional Disparities in R\&D Intensity of Technology-Intensive Industries in the Czech Republic (2004)

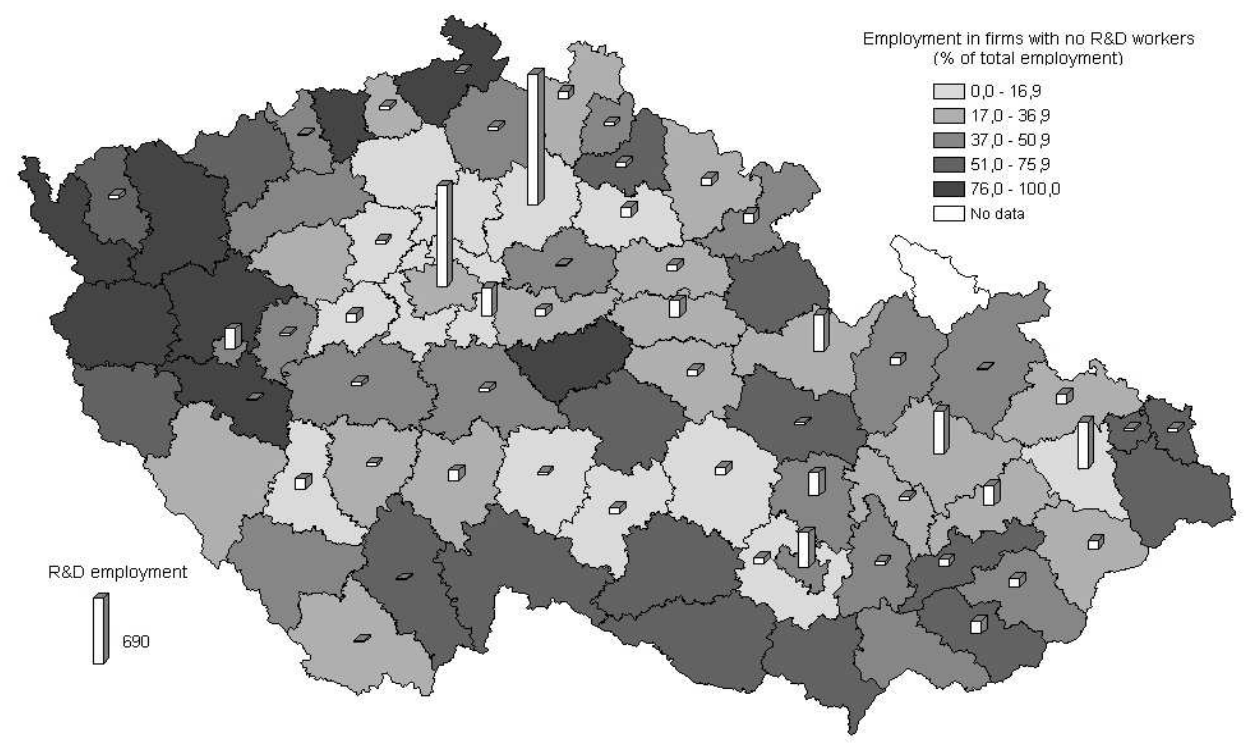

Notes: districts with less than $10 \mathrm{R} \& \mathrm{D}$ workers were neglected.

Source: Ministry of Industry and Trade 2006 